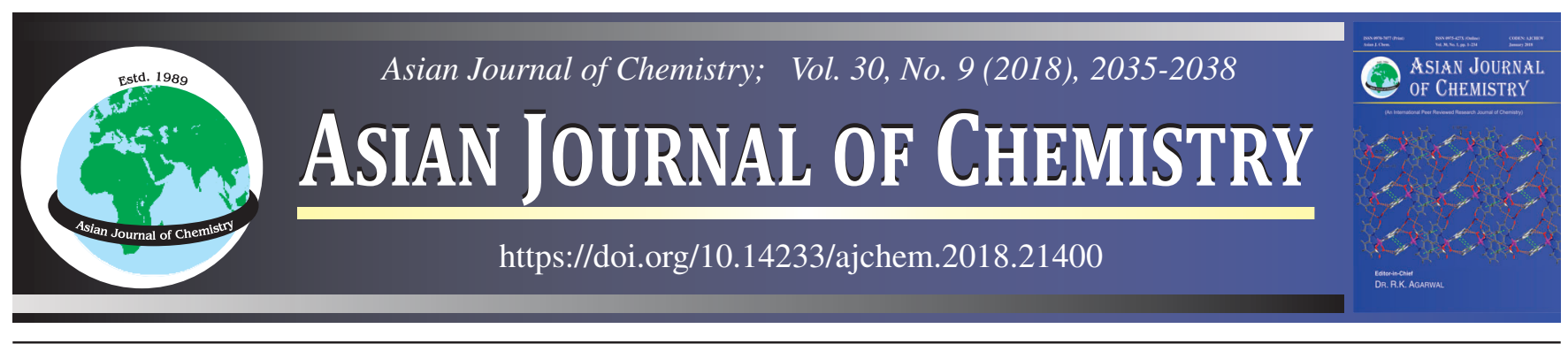

\title{
Protease Producers Predominate Cultivable Hydrolytic Bacteria Isolated from Liquid Biomedical Waste
}

\section{Stalis Norma Ethica ${ }^{1, *}$, Sakti Imam Muchlissin ${ }^{2}$, Ragil Saptaningtyas $^{1}$ and Agus Sabdono ${ }^{2}$}

${ }^{1}$ Faculty of Nursing and Health Sciences, Universitas Muhammadiyah Semarang, Semarang, Indonesia

${ }^{2}$ Faculty of Fisheries and Marine Sciences, Universitas Diponegoro, Semarang, Indonesia

*Corresponding author: E-mail: norma@unimus.ac.id

Received: 23 April 2018;

Accepted: 11 July 2018;

Published online: 31 July 2018

AJC-19016

\begin{abstract}
Hydrolytic bacteria are known for their crucial role in the bioconversion of organic matters mainly present in biomedical waste, making them advantageous in bioremediation. Analysis of abundance and colony diversity of culturable bacteria producing hydrolytic enzymes isolated from liquid biomedical waste of two different classes of hospitals in Semarang city, Central Java was carried out. Bacterial cultivation on nutrient agar slants resulted in total 26 viable colonies from inlet samples of Rumah Sakit Umum Roemani Muhammadiyah (R1) and Rumah Sakit Umum Daerah KRMT Wongsonegoro (R2) hospitals. Both hospitals represented two different classes of hospitals in Semarang ( $\mathrm{C}$ and B, where B class is higher grade). Screening for production of four main hydrolytic enzymes (protease, lipase, amylase and cellulose) on all cultivable colonies obtained in this study. The results showed that all of them were capable of producing more than one type of hydrolytic enzymes. The composition was as follows: Protease producers (26 colonies), amylase producers (14 colonies), cellulose producers (13 colonies) and lipase producers (10 colonies). This study demonstrated that primary inlet of hospitals is a rich source of hydrolytic bacteria, where extracellular protease producers were found to be the main population of this group. In Semarang case, the inlet of lower class of hospital appeared to be more potential source of these hydrolytic bacteria than that of higher class one.
\end{abstract}

Keywords: Protease producers, Clinical waste, Cultivable hydrolytic bacteria, Colony viability, Semarang hospital.

ᄂ _ - - - - - - - - - - - - - - - - - - - - - - - - - - - -

\section{INTRODUCTION}

Inadequate management of healthcare waste is a serious concern in many developing countries including Indonesia due to the risks posed to human health and the environment $[1,2]$. Previous investigation revealed that the biomedical waste contains mixed bacterial community with some being pathogenic and pose a public health hazard to both health workers and other community members. For example, in Nepal the healthcare liquid wastes were laden with MDR bacteria and seemed to pose a huge public health threat in the transfer of such resistance to the bacterial pathogens causing community acquired infections. Therefore, adequate treatment measures should be given to all biomedical waste before disposal $[3,4]$.

Today, newer waste treatment facilities including plasma pyrolysis, encapsulation, inertization have been introduced, to replace older facilities such as incineration as toxic fumes (dioxins and furans) are produced which are harmful to both health and environment. Wastewater treatment plants (WWTP) were also thought to remove the antimicrobial resistance genes during the processing of the waste, which is being generated from the hospitals [5-7]. In developing countries, however, wastewater treatment plant is still considered costly [2].

As part of biotechnology, bioremediation is a natural breakthrough to manage or to degrade wastes. It is eco-friendly and much cost effective as compared to other traditional method such as incineration, autoclave or common wastewater treatment plan. in situ Bioremediation provides the treatment at contaminated sites and avoiding excavation and transport of contaminants, means there is no need to excavate the water for remediation [8].

Patterns of enzyme activities in environmental samples are a useful tool for assessing the functional diversity of microbial communities and organic matter turnover [9]. Hydrolytic

This is an open access journal, and articles are distributed under the terms of the Creative Commons Attribution-NonCommercial 4.0 International (CC BY-NC 4.0) License, which allows others to copy and redistribute the material in any medium or format, remix, transform, and build upon the material, as long as appropriate credit is given and the new creations are licensed under the identical terms. 
bacteria are believed to be a group of bacteria producing extracellular hydrolytic enzymes potential for use as a microbial consortium in the bioremediation of biomedical waste of hospital. However, in Indonesia and worldwide, there has been scarcely report about hydrolytic bacteria regarding with their potential as bioremediation agent of biomedical waste from hospitals [2]. In previous study, the characterization of a bacterial strain secreting hydrolytic lipase, Alcaligenes sp. JG3, which is capable of degrading fat and glycerol making it potential to be used as effective biodegradation agent of organic waste. Nevertheless, the mentioned strain wasknown as pathogenic $[2,10,11]$.

According to Indonesian regulation on hospital classification (Permenkes RI No. 340/MENKES/PER/III, 2010), there are four main categories of hospitals i.e. A, B, C and D classes of hospitals representing the top to decreased grades of hospitals, respectively. In general, the A class of hospital in Indonesia has most complete facilities, while the D class (non-accredited hospital) has the least installations of all. In particular, several facilities differing B-from C-classes of hospitals include medical rehabilitation, sub-specialized medical service, polyclinics, specialized radiology installation, specialized anaesthetic service, leprosy reconstruction and septic surgery, library and discussion room, which are present in B-class, but missing in C-class hospitals. Yet, in terms of waste treatment, B and C hospital classes are equally mandated to have standard wastewater treatment plant and temporary waste storage, where incineration service could be provided by third party.

The non-incineration method such as bioremediation is the recommended way to treat biomedical waste for developing countries according to World Health Organization [12]. Ethica et al. [13] stated that the isolation of indigenous bacteria capable of producing hydrolytic enzymes is an initial yet crucial step in the development of bioremediation agent to treat liquid biomedical waste. This study aimed to analyze the abundance and characteristics of cultivable bacterial coloniesisolated from liquid biomedical waste of hospitals in Central Java and investigating their ability to produce hydrolytic enzymes (lipase, protease, cellulase, and amylase) for bioremediation purposes.

\section{EXPERIMENTAL}

Materials used in this study were liquid biomedical waste samples from two hospitals' inlets, nutrient agar (Oxoid, UK Cat. \#CM0003), nutrient broth (Oxoid, UK Cat. \#CM0001), sodium chloride (Merck, Germany), agar, tributyrin agar media (Sigma Aldrich, USA Cat. \#91015), aquadest, sterile skim milk (Sigma Aldrich), starch, iodine and KI solutions and carboxymethyl cellulose (all from Merck, Germany). The equipments used included personal protection equipment like anti-infection kit (DuPont, USA Cat. \#32982923), screwed cap sterile bottles, petri dish, shaker, autoclave, refrigerator, laminar flow and UV lamp.

Microorganism isolation: Wastewater samples were serially diluted and inoculated onto the nutrient agar medium separately. The plates were incubated at $35^{\circ} \mathrm{C}$ for $24-48 \mathrm{~h}$ followed by colony purification, which was conducted in three replicates. Morphologically distinct colonies were collected and described in terms of color, shape, edge and surface.
Lipolytic activity: In order to determine that the microorganisms were lipase and esterase producer, the microorganisms were cultivated in tributyrin agar media following the manufacturer's direction (Sigma Aldrich's data sheet for Cat. \# 91015). After incubation, the clear zone of hydrolysis around the colonies indicated the lipase production.

Protease activity: Qualitative protease activity assay was evaluated on skim milk medium containing $5.6 \mathrm{~g}$ nutrient agar (Oxoid, UK) and $2.2 \mathrm{~g}$ sterile skim milk (Sigma Aldrich, USA) per $220 \mathrm{~mL}$. The formation of clear zone ( $12 \mathrm{~mm}$ or more) in the medium surrounding the well indicated positive protease activity [14].

Amylolytic activity: The obtained colonies were also screened for their ability to produce amylase on a selective medium containing $1 \%$ soluble starch as substrate as reported by Mazzucotelli et al. [15]. After incubation, the plates were flooded with $1 \%$ iodine in $2 \% \mathrm{KI}$. The appearance of clear zones around the well ( $8 \mathrm{~mm}$ or more) indicated a positive amylase activity.

Cellulolytic activity: Bacterial isolates were screened for their cellulase activity using a selective medium containing $1 \%$ CMC (carboxymethyl-cellulose) as substrate [16]. After incubation, the plates were stained with Congo red dye and washed. A positive cellulase activity was detected by the formation of a yellow halo (8 $\mathrm{mm}$ or more) against a red background [15].

\section{RESULTS AND DISCUSSION}

The purpose of this study is to evaluate bacterial colonies and isolate hydrolytic bacteria from inlets of different classes of hospitals had been conducted in Semarang, the capital city of Central Java Province of Indonesia. Standard sampling procedures were followed involving the use of fully covered personal protection equipment and anti-infection kit (DuPont, USA) as well as vaccination for research workers prior to sampling step [2].

Twenty-six distinct bacterial colonies were obtained from two different liquid biomedical waste inlets of two different classes of hospitals in Central Java (Table-1). R1 represented RSU Roemani Muhammadiyah (C-class) hospital, whereas R2 represented RSUD KRMT Wongsonegoro (B-class) hospital. As seen in Table-1, total abundance of bacteria obtained from $\mathrm{R} 1$ group sample $\left(2.38 \times 10^{5} / \mathrm{mL}\right)$ was not much different from that from R2 $\left(2.27 \times 10^{5}\right)$ during April-May 2017 (dry season) in Indonesia. Subsequently, all of the colonies collected were differentiated based on morphology characteristics in terms of colour, opacity, shape, margin, and surface to ensure that these colonies come from different species of bacteria.

In this study, all bacterial isolates were first cultivated on nutrient agar slants and then tested for hydrolytic enzyme production (Table-2). Seventeen of the total isolates could be obtained from R1 site, where all of them showed ability to produce extracellular proteolytic. Aside of producing protease, some of them were at the same time could produce other hydrolytic enzymes either lipase (7 isolates), amylase (10 isolates), or cellulose (9 isolates). On the other hand, only 9 bacterial isolates in total were obtained from R2. Interestingly, all R2 isolates similarly showed proteolytic activityas all R1 isolates did. At the same time some of them were also able to produce other hydrolytic enzymes, i.e. lipase (3 isolates), amylase (4 isolates), and cellulose (4 isolates). 


\begin{tabular}{|c|c|c|c|c|c|c|}
\hline \multicolumn{7}{|c|}{$\begin{array}{c}\text { TABLE-1 } \\
\text { IDENTIFIED BACTERIAL COLONIES AND THEIR }\end{array}$} \\
\hline \multirow{2}{*}{ Sample code* } & \multirow{2}{*}{ Collection date } & \multirow{2}{*}{$\begin{array}{l}\text { Abundance } \\
\text { (CFU) }\end{array}$} & \multicolumn{4}{|c|}{ Colony characteristics } \\
\hline & & & Colour & Shape & Margin & Surface \\
\hline R1.1 & \multirow{17}{*}{ April 3, 2017} & \multirow{17}{*}{$2.38 \times 10^{5}$} & Yellow & Round & Pulvinate & Raised \\
\hline $\mathrm{R} 1.2$ & & & Opaque white & Round & Pulvinate & Raised \\
\hline $\mathrm{R} 1.3$ & & & Transparent white & Round & Pulvinate & Raised \\
\hline $\mathrm{R} 1.4$ & & & Opaque white & Round & Umbonate & Flat \\
\hline $\mathrm{R} 1.5$ & & & Opaque white & Irregular & Curled & Flat \\
\hline R1.6 & & & Vanilla & Round & Pulvinate & Convex \\
\hline $\mathrm{R} 1.7$ & & & Opaque white & Rhizoid & Filamentous & Flat \\
\hline $\mathrm{R} 1.8$ & & & Opaque white & Irregular & Undulated & Flat \\
\hline R1.9 & & & Light yellow & Irregular & Curled & Convex \\
\hline $\mathrm{R} 1.10$ & & & White & Irregular & Curled & Convex \\
\hline $\mathrm{R} 1.11$ & & & Light pink & Round & Pulvinate & Convex \\
\hline $\mathrm{R} 1.12$ & & & Transparent white & Punctiform & Pulvinate & Convex \\
\hline $\mathrm{R} 1.13$ & & & White & Filamentous & Filamentous & Flat \\
\hline $\mathrm{R} 1.14$ & & & Transparent white & Punctiform & Pulvinate & Flat \\
\hline $\mathrm{R} 1.15$ & & & Opaque white & Punctiform & Curled & Flat \\
\hline $\mathrm{R} 1.16$ & & & Yellow & Punctiform & Pulvinate & Flat \\
\hline $\mathrm{R} 1.17$ & & & White & Punctiform & Pulvinate & Convex \\
\hline $\mathrm{R} 2.1$ & \multirow{9}{*}{ May 15, 2017} & \multirow{9}{*}{$2.27 \times 10^{5}$} & Transparent white & Round & Pulvinate & Convex \\
\hline $\mathrm{R} 2.2$ & & & Opaque white & Irregular & Curled & Flat \\
\hline $\mathrm{R} 2.3$ & & & Opaque white & Irregular & Curled & Convex \\
\hline $\mathrm{R} 2.4$ & & & Opaque white & Round & Pulvinate & Convex \\
\hline $\mathrm{R} 2.5$ & & & Transparent white & Irregular & Curled & Convex \\
\hline $\mathrm{R} 2.6$ & & & Yellow & Round & Pulvinate & Convex \\
\hline $\mathrm{R} 2.7$ & & & Yellow & Punctiform & Pulvinate & Convex \\
\hline $\mathrm{R} 2.8$ & & & White & Filamentous & Undulated & Convex \\
\hline $\mathrm{R} 2.9$ & & & Dark yellow & Irregular & Curled & Convex \\
\hline \multicolumn{7}{|c|}{$\begin{array}{l}\text { *R1 = Rumah Sakit Umum (RSU) Roemani Muhammadiyah, Semarang (C-C } \\
\text { Wongsonegoro, Semarang (B-Class hospital). }\end{array}$} \\
\hline \multicolumn{7}{|c|}{$\begin{array}{c}\text { TABLE-2 } \\
\text { IDENTIFIED STRAINS AND THEIR HYDROLYTIC PROFILE }\end{array}$} \\
\hline \multirow{2}{*}{ Sample code* } & \multicolumn{6}{|c|}{ Extracellular enzyme production tests** } \\
\hline & Lipolytic & Pro & ytic & ylolytic & Sellulolytic & Hydrolytic \\
\hline R1.1 & - & & & + & ++ & $\checkmark$ \\
\hline $\mathrm{R} 1.2$ & - & & & ++ & ++ & $\checkmark$ \\
\hline $\mathrm{R} 1.3$ & - & & & ++ & ++ & $\checkmark$ \\
\hline $\mathrm{R} 1.4$ & - & & & ++ & ++ & $\checkmark$ \\
\hline $\mathrm{R} 1.5$ & + & & & - & - & $\checkmark$ \\
\hline R1.6 & + & & & - & - & $\checkmark$ \\
\hline $\mathrm{R} 1.7$ & - & & & ++ & ++ & $\checkmark$ \\
\hline $\mathrm{R} 1.8$ & - & & & ++ & + & $\checkmark$ \\
\hline $\mathrm{R} 1.9$ & - & & & - & - & $\checkmark$ \\
\hline $\mathrm{R} 1.10$ & + & & & - & - & $\checkmark$ \\
\hline $\mathrm{R} 1.11$ & - & & & + & ++ & $\checkmark$ \\
\hline $\mathrm{R} 1.12$ & - & & & - & - & $\checkmark$ \\
\hline $\mathrm{R} 1.13$ & + & & & - & - & $\checkmark$ \\
\hline $\mathrm{R} 1.14$ & - & & & ++ & + & $\checkmark$ \\
\hline $\mathrm{R} 1.15$ & ++ & & & + & - & $\checkmark$ \\
\hline $\mathrm{R} 1.16$ & ++ & & & - & - & $\checkmark$ \\
\hline $\mathrm{R} 1.17$ & + & & & ++ & + & $\checkmark$ \\
\hline $\mathrm{R} 2.1$ & - & & & ++ & - & $\checkmark$ \\
\hline $\mathrm{R} 2.2$ & - & & & - & - & $\checkmark$ \\
\hline $\mathrm{R} 2.3$ & - & & & ++ & ++ & $\checkmark$ \\
\hline R2.4 & - & & & - & + & $\checkmark$ \\
\hline $\mathrm{R} 2.5$ & ++ & & & + & - & $\checkmark$ \\
\hline R2.6 & ++ & & & + & + & $\checkmark$ \\
\hline $\mathrm{R} 2.7$ & + & & & - & + & $\checkmark$ \\
\hline $\mathrm{R} 2.8$ & - & & & - & - & $\checkmark$ \\
\hline R2.9 & - & & & - & - & $\checkmark$ \\
\hline$\Sigma$ & 10 & & & 14 & 13 & 26 \\
\hline
\end{tabular}

*R1 = Rumah Sakit Umum (RSU) Roemani Muhammadiyah, Semarang (C-Class hospital); R2 = Rumah Sakit Umum Daerah (RSUD) KRMT Wongsonegoro, Semarang (B-Class hospital). **Tests were performed in duplicate. 
Results from this study showed that proteolytic producers predominate hydrolytic bacterial colonies isolated from liquid biomedical waste of hospitals in Semarang. These findings were quite similar with those reported by Ye and Zhang [17] demonstrating that proteobacteria (Deltaproteobacteria) dominated bacterial classes in the influent or inlet sample of a municipal (Shatin) wastewater treatment plant in Hong-Kong. However, there has been no report associated with the abundance of hydrolytic bacteria found in samples obtained from wastewater treatment plant of hospitals in other countries including Hong-Kong by far. Chitnis et al. [18] studied about bacterial population changes in hospital effluent treatment plant in central India, but not focusing on hydrolytic bacterial community. The scarcity of studies about indigenous microbial populations potential for bioremediation of hospital biomedical waste is perceivable because the work requires the researchers to strictly adhere regulations and medical safety procedures [19].

The present study contributes to better understanding of the diversity of cultivable hydrolytic bacteria in liquid biomedical waste habitats. The high concentrations of hydrolytic enzyme producing bacteria associated with untreated liquid biomedical waste obtained from primary inlet of two hospitals in Semarang (Roemani and KRT Wongsonegoro) suggests that primary inlet of hospitals is a potentially rich source of hydrolytic bacteria. The capability of bacterial strains obtained in this study to produce hydrolytic enzymes in more than one forms is a strong indication that they are capable to degrade organic matters. Biomedical wastes are source of organic wastes as they contain tissues, blood and other body fluid. The capability of these bacteria to handle liquid biomedical waste could be measured in term of BOD, COD, nitrate, phosphate, TSS and TDS. If capable to decrease these water pollution parameters, particular bacterial isolates may be used for bioremediation to control water pollution [20].

\section{ACKNOWLEDGEMENTS}

The authors gratefully thank to Indonesian Ministry of Research, Technology and Higher Education (Kemenristek DIKTI) for financial support through Penelitian Pasca Doktor (PPD, Postdoctoral Research) grant scheme No. 006/SP2H/LT/DRPM/ II/2016. Special gratitude is honored to both Rumah Sakit Umum (RSU) Roemani Muhammadiyah and Rumah Sakit Umum Daerah (RSUD) KRMT Wongsonegoro in Semarang, as bacterial sampling location of this study. High appreciation is also presented to Laboratorium Terpadu and FPIK (Fakultas Perikanan dan Ilmu Kelautan) Laboratorium, Universitas Diponegoro, for supporting laboratory facilities needed in this work.

\section{CONFLICT OF INTEREST}

The authors declare that there is no conflict of interests regarding the publication of this article.

\section{REFERENCES}

1. L. Sefouhi, M. Kalla, L. Bahmed and L. Aouragh, Int. J. Environ. Sci. Dev., 4, 442 (2013); https://doi.org/10.7763/IJESD.2013.V4.390.

2. S.N. Ethica and A. Sabdono, Bio-Remediation Potential of Hydrolytic Bacteria Isolated from Hospital Liquid Biomedical Waste in Central Java, Proceedings of The 3rd World Congress on New Technologies (NewTech'17), Roma, Italy, June 6-8 (2017).

3. D.R. Sharma, B. Pradhan and S.K. Mishra, Kathmandu Univ. Med. J., 8, 40 (2010).

4. R.N. Osagie, A.A. Eyaufe and F. Ireye, Int. J. Public Health Sci., 5, 51 (2016).

5. L. Singhal, A.K. Tuli and V. Gautam, Indian J. Med. Microbiol., 35, 194 (2017).

6. F. Barancheshme and M. Munir, Front. Microbiol., 8, 2603 (2017); https://doi.org/10.3389/fmicb.2017.02603.

7. J. Quach-Cu, B. Herrera-Lynch, C. Marciniak, S. Adams, A. Simmerman and R.A. Reinke, Water, 10, 37 (2018);

https://doi.org/10.3390/w10010037.

8. C.C.Azubuike, C.B. Chikere and G.C. Okpokwasili, World J. Microbiol. Biotechnol., 32, 180 (2016); https://doi.org/10.1007/s11274-016-2137-x.

9. M. Ferrer, O. Golyshina, A. Beloqui and P.N. Golyshin, Curr. Opin. Microbiol., 10, 207 (2007); https://doi.org/10.1016/j.mib.2007.05.004.

10. S.N. Ethica and T.J. Raharjo, Ph.D. Thesis, Detection of Genes Involved in Glycerol Metabolism of Alcaligenes sp. JG3, Universitas Gadjah Mada, Indonesia (2014).

11. S.N. Ethica, R. Saptaningtyas, S.I. Muchlissin and A. Sabdono, Health Technol., 1-16 (2018); https://doi.org/10.1007/s12553-018-0232-8.

12. World Health Organization, Report on Health-Care Waste Management (HCWM) Status in Countries of the South-East Asia Region (2017).

13. S.N. Ethica, O. Oedjijono, E. Semiarti, J. Widada and T.J. Raharjo, BIOTROPIA-The Southeast Asian J. Trop. Biol., 25, 1 (2018).

14. O. Pérez-Borla, L.A. Davidovich and S.I. Roura, LWT-Food Chem. Technol., 43, 298 (2010); https://doi.org/10.1016/j.lwt.2009.07.006

15. C.A. Mazzucotelli, A.G. Ponce, C.E. Kotlar and M.D. Moreira, Food Sci. Technol., 33, 295 (2013); https://doi.org/10.1590/S0101-20612013005000038

16. H. Ariffin, N. Abdullah, M.S.U. Kalsom, Y. Shirai and M.A. Hassan, Int. J. Eng. Technol., 3, 47 (2006); https://doi.org/10.1263/jbb.106.231.

17. L. Ye and T. Zhang, Appl. Microbiol. Biotechnol., 97, 2681 (2013); https://doi.org/10.1007/s00253-012-4082-4.

18. V. Chitnis, S. Chitnis, K. Vaidya, S. Ravikant, S. Patil and D.S. Chitnis, Water Res., 38, 441 (2004); https://doi.org/10.1016/j.watres.2003.09.038.

19. S.N. Ethica, E. Semiarti, J. Widada, O. Oedjijono and T. Joko Raharjo, J. Food Saf., 37, e12345 (2017); https://doi.org/10.1111/jfs.12345.

20. N. Sonune and A. Garode, Curr. World Environ., 10, 619 (2015); https://doi.org/10.12944/CWE.10.2.27. 